\title{
BEING DARK IS BETTER: A FERAL PIGEON PLUMAGE POLYMORPHISM AS A RESPONSE TO URBAN ENVIRONMENTS IN SLOVAKIA
}

\author{
ALEXANDER CSANÁDY $\bowtie$, SILVIA DURANKOVÁ \\ University of Prešov, Faculty of Humanities and Natural Sciences, Department of Biology, 17. novembra 1, 08001 Prešov, Slovak Republic; e-mail: alexander. \\ canady@gmail.com, silvia.durankova@unipo.sk \\ $\triangle$ Corresponding author
}

Received: 26 July 2020 / Accepted: 3 September 2020

Abstract

Csanády A., Duranková S.: Being dark is better: A feral pigeon plumage polymorphism as a response to urban environments in Slovakia. Ekológia (Bratislava), Vol. 40, No. 1, p. 54-61, 2021.

The purpose of this study was to determine the distribution and plumage phenotypes of the feral pigeon, Columba livia forma urbana (Gmelin, 1789), in Slovakia. Censuses carried out in the built-up areas of 16 towns and cities from November to February (2012-2018) counted and evaluated 3,123 individual birds. The most frequent were melanic colored birds (checker, T-pattern and spread phenotypes), which predominated in the population $(51.6 \%, n=1,613)$, followed by paler ones $(42.1 \%, n=1,316)$ and other types $(6.2 \%, n=194)$. A statistically significant difference was confirmed among the melanic and paler plumage phenotypes $\left(\chi^{2}=81.49, \mathrm{df}=15, \mathrm{p}<0.0001\right)$. Correlation confirmed the different importance of city area and human density on the maintenance of dark and/or pale pigeons living in cities.

Key words: color, feather variability, urbanization process.

\section{Introduction}

The feral pigeon, Columba livia forma urbana (Gmelin, 1789), is one of the most numerous urban bird species in many European and American cities (Janiga, 1991; Johnston, Janiga, 1995; Saari, 1997; Obukhova, 2001, 2007, 2011; Sacchi et al., 2002; Hetmański, Jarosiewicz, 2008; Ferman et al., 2010; Kowalski et al., 2011; Jacquin et al., 2010; Čanády, Mošanský, 2013, 2016; Vickrey et al., 2018; Pardo et al., 2018). The mentioned authors showed that large concentrations of these birds were primarily observed in old town centers, in church towers, museums, theatres, railway stations, and attics. The pigeons nest and breed mainly under roofs and in niches of old houses, on the balconies of panel blocks of flats, and in factories and bridge constructions. Moreover, the mentioned authors confirmed the significant diversity in pigeon plumages among the populations and reported adaptation mechanisms and a direction of selection favoring different morphs.

Changes in the phenotype distribution in populations were also associated with changes in the social structure of the human population (Obukhova, 2007). Urbanization is the most dynamic phenomenon worldwide, and many species colonize urban environments. The urbanization process introduces important changes in habitats or creates new urban ecosystems where ecological functions are affected by human activities (e.g., Čanády, Mošanský, 2017; Tryjanowski et al., 2017). The higher frequency of some phenotypes in urban versus rural/wild areas has led to the assumption that directional selection occurs in urban habitats and may thereby favor some behavioral and physiological traits in urban animal populations compared to rural ones (Jokimäki, Suhonen, 1998; Obukhova, 2007; Jacquin et al., 2011, 2012, 2013a,b; Przybylszka et al., 2012; Récapet et al., 2013; Čanády, Mošanský, 2017; Tryjanowski et al., 2017). Obukhova (2007) showed that the blue color was more adaptive in natural habitats. This morph was found in rural populations more frequently than in urban ones. Moreover, constant and rich sources of food in urban habitats. Melanistic birds were accumulated, because their behavioral characteristics make them more resistant to a high population density. She assumed, that new possibilities for the formation and maintenance of polymorphism appeared when an increase in population density was accompanied by changes in behavioral stereotypes. The ability to spread to new subniches leads to ecological segregation of the species, thereby increasing its resistance to sudden fluctuations of environmental conditions. Behavioral adaptation in colonies of the blue rock pigeons results in a structured community in which genetic exchange between groups is maintained at a certain level and the gene pool of the total population is preserved.

In this context, melanin-based coloration is a good candidate trait to investigate the effect of urbanization process (i.e., selection forces associated with urbanization), because it has a strong genetic basis (Roulin, 2004). A number of studies

(c) The Author(s) 2021. This is an open access article distributed under the terms of the CC BY-NC-ND license.

https://content.sciendo.com/view/journals/eko/eko-overview.xml 
Table 1. Basic characterisation of the studied cities with feral pigeons (Columba livia f. urbana) in eastern Slovakia.

\begin{tabular}{|l|c|c|c|c|}
\hline City & \multicolumn{1}{|c|}{$\begin{array}{c}\text { GPS } \\
\text { coordinates }\end{array}$} & $\begin{array}{c}\text { City area } \\
\left(\mathbf{k m}^{2}\right)\end{array}$ & $\begin{array}{c}\text { Human density } \\
\text { (inhab./km }\end{array}$ & $\begin{array}{c}\text { Height } \\
\text { m a.s.l. }\end{array}$ \\
\hline Košice & $48^{\circ} 43^{\prime} 12^{\prime \prime} \mathrm{N} / 21^{\circ} 15^{\prime} 29^{\prime \prime} \mathrm{E}$ & 237.05 & 984.87 & 208 \\
\hline Stropkov & $49^{\circ} 12^{\prime} 18^{\prime \prime} \mathrm{N} / 21^{\circ} 39^{\prime} 05^{\prime \prime} \mathrm{E}$ & 24.67 & 431.86 & 202 \\
\hline Svidník & $49^{\circ} 18^{\prime} 20^{\prime \prime} \mathrm{N} / 21^{\circ} 34^{\prime} 04^{\prime \prime} \mathrm{E}$ & 20.20 & 549.31 & 230 \\
\hline Prešov & $49^{\circ} 00^{\prime} 00^{\prime \prime} \mathrm{N} / 21^{\circ} 14^{\prime} 00^{\prime \prime} \mathrm{E}$ & 70.43 & 1265.63 & 255 \\
\hline Bardejov & $49^{\circ} 17^{\prime} 32^{\prime \prime} \mathrm{N} / 21^{\circ} 16^{\prime} 35^{\prime \prime} \mathrm{E}$ & 72.39 & 450.16 & 323 \\
\hline Medzilaborce & $49^{\circ} 16^{\prime} 15^{\prime \prime} \mathrm{N} / 21^{\circ} 54^{\prime} 14^{\prime \prime} \mathrm{E}$ & 47.48 & 139.26 & 326 \\
\hline Giraltovce & $49^{\circ} 06^{\prime} 42^{\prime \prime} \mathrm{N} / 21^{\circ} 31^{\prime} 00^{\prime \prime} \mathrm{E}$ & 11.4 & 377.55 & 195 \\
\hline Vranov nad Toplou & $48^{\circ} 52^{\prime} 51^{\prime \prime} \mathrm{N} / 21^{\circ} 40^{\prime} 24^{\prime \prime} \mathrm{E}$ & 34.36 & 657.42 & 132 \\
\hline Michalovce & $48^{\circ} 44^{\prime} 57^{\prime \prime} \mathrm{N} / 21^{\circ} 54^{\prime} 05^{\prime \prime} \mathrm{E}$ & 52.81 & 741.36 & 114 \\
\hline Trebišov & $48^{\circ} 38^{\prime} 01^{\prime \prime} \mathrm{N} / 21^{\circ} 43^{\prime} 02^{\prime \prime} \mathrm{E}$ & 70.16 & 350.44 & 109 \\
\hline Humenné & $48^{\circ} 56^{\prime} 09^{\prime \prime} \mathrm{N} / 21^{\circ} 54^{\prime} 24^{\prime \prime} \mathrm{E}$ & 28.76 & 1168.04 & 157 \\
\hline Moldava nad Bodvou & $48^{\circ} 36^{\prime} 23^{\prime \prime} \mathrm{N} / 21^{\circ} 00^{\prime} 01^{\prime \prime} \mathrm{E}$ & 19.77 & 573.70 & 216 \\
\hline Rožňava & $48^{\circ} 39^{\prime} 30^{\prime \prime} \mathrm{N} / 20^{\circ} 31^{\prime} 51^{\prime \prime} \mathrm{E}$ & 45.61 & 420.65 & 313 \\
\hline Štítnik & $48^{\circ} 39^{\prime} 28^{\prime \prime} \mathrm{N} / 20^{\circ} 21^{\prime} 54^{\prime \prime} \mathrm{E}$ & 34.54 & 44.01 & 284 \\
\hline Revúca & $48^{\circ} 40^{\prime} 59^{\prime \prime} \mathrm{N} / 20^{\circ} 06^{\prime} 48^{\prime \prime} \mathrm{E}$ & 38.87 & 315.13 & 318 \\
\hline Velký Šariš & $49^{\circ} 02^{\prime} 18^{\prime \prime} \mathrm{N} / 21^{\circ} 11^{\prime} 30^{\prime \prime} \mathrm{E}$ & 25.73 & 240.38 & 269 \\
\hline
\end{tabular}

have reported differences in pigeon melanin-based coloration between urban and rural areas (Obukhova, 2001, 2007, 2011), and it has been frequently reported to covary with other phenotypic traits, such as immunity, behavior, or reproduction (Ducrest et al., 2008; Jacquin et al., 2010, 2011; 2012, 2013a,b; Récapet et al., 2013).

In consequence, more dark, that is, melanic pigeons were observed in city centers than on their peripheries. These differences were demonstrated in Gdańsk (Poland) by Hetmański, Jarosiewicz (2008), who confirmed that bluebar birds were dominant in the old city center, while melanic individuals prevailed in the more recently built housing estate districts surrounding the city center. Čanády, Mošanský (2013) showed for Košice's populations (Slovakia) that melanic birds were more common than blue-bars. Similar ratio in color were observed between the center and the periphery of a city.

Several authors (Lofts et al., 1966; Hetmański, 2008; Kowalski et al., 2011) have devoted greater attention to ecological processes related to the maintenance of coloration polymorphism. Lofts et al. (1966) showed that melanic birds were seen more often in cities because their gonads are active even in winter in contrast to blue-bars, and they thus produce more pups during the longer breeding season. In contrast, Kowalski et al. (2011) disproved the thesis that climatic conditions significantly shaped the polymorphism of feral pigeons. Hetmański (2008) considers the founder's effect, that is, the different history of each population and varying environmental conditions in cities, to be the most important factor determining the frequency of color and phenotypic forms in the feral pigeon population.

On the other hand, several authors (Gasparini et al., 2011; Jacquin et al., 2011, 2012, 2013a,b; Récapet et al., 2013) reported an adaptation to the urban environment which brings some benefits based on melanin-based coloration. It was confirmed that checkered and T-pattern pigeons had higher fre- quencies of successful fledging from the nest and longer (up to year-round) breeding seasons; in addition, they are able to sequester more toxic heavy metals in plumage pigments through chelation (Lofts et al., 1966; Janiga, 1991; Chatelain et al., 2014, 2016; Vickrey et al., 2018).

According to the cited studies, the properties associated with darker coloring are consistent with those of individuals in urban and/or stressful areas. All the findings suggest that melanin-based coloration reflects adaptations to different environmental conditions (Roulin, 2004). Therefore, directional selection could be expected to affect this property. The suitability of dark individuals of several bird species should be higher than that of paler individuals in urban areas, which could result from differences in survival, reproductive success, and habitat selection (Roulin, Altwegg, 2007; Roulin et al., 2000, 2008, 2010; Van den Brink et al., 2012; Saino et al., 2013).

The aim of this study was to evaluate the plumage phenotype of feral pigeons in the urban areas of 16 towns and cities in eastern Slovakia. If melanin-based coloration reflects an adaptation to the urban environment, we assumed that melanic birds would occur in higher numbers than paler birds.

\section{Material and methods}

The study was conducted within the administrative borders of 16 cities or towns in eastern Slovakia (Table 1). With the exception of Košice, which represents one of the three largest cities in Slovakia in terms of area, all the other cities were medium or smaller in size based on the area in $\mathrm{km}^{2}$. In this study, we also used our previously published data from Košice (see Čanády, Mošanský, 2013) and the towns of Stropkov and Svidník (see Čanády, Mošanský, 2016). Censuses of pigeons were conducted by walking through cities in built-up areas during the autumn and winter seasons, that is, from November 2012 to February 2019. According to Hetmański, Jarosiewicz 
Table 2. The number of phenotype forms distinguished in feral pigeon (Columba livia f. urbana) populations in the urban environments of eastern Slovakian cities.

\begin{tabular}{|l|c|c|c|c|c|c|c|c|c|}
\hline City & Date & Blanc & Wild & Checker & T-pattern & Spread & Rufous & Other & Summary \\
\hline Košice & $2013^{*}$ & 10 & 431 & 246 & 335 & 73 & 22 & 104 & $\mathbf{1 2 2 1}$ \\
\hline Stropkov & $2016^{* *}$ & 2 & 11 & 5 & 13 & 7 & 1 & 3 & $\mathbf{4 2}$ \\
\hline Svidník & $2016^{* *}$ & & 15 & 13 & 15 & 3 & 4 & 5 & $\mathbf{5 5}$ \\
\hline Prešov & $18-20$ October 2018 & 12 & 205 & 49 & 168 & 12 & 6 & 6 & $\mathbf{4 5 8}$ \\
\hline Bardejov & 26 October 2018 & 2 & 24 & 10 & 18 & & 3 & $\mathbf{5 7}$ \\
\hline Medzilaborce & 27 October 2018 & & 23 & 1 & 20 & 8 & 2 & & $\mathbf{5 4}$ \\
\hline Giraltovce & 27 October 2018 & & 11 & 4 & 8 & 11 & 1 & & $\mathbf{3 5}$ \\
\hline Vranov nad Toplou & 27 October 2018 & & 75 & 4 & 22 & & 5 & 1 & $\mathbf{1 0 7}$ \\
\hline Michalovce & 27 October 2018 & 2 & 51 & 4 & 34 & 10 & & 1 & $\mathbf{1 0 2}$ \\
\hline Trebišov & 27 October 2018 & 8 & 177 & 20 & 184 & 31 & 20 & & $\mathbf{4 4 0}$ \\
\hline Humenné & 9 February 2019 & 2 & 17 & 14 & 14 & 1 & 1 & $\mathbf{4 9}$ \\
\hline Moldava nad Bodvou & 16 February 2019 & 3 & 134 & 82 & 55 & 12 & 6 & & $\mathbf{2 9 2}$ \\
\hline Rožňava & 17 February 2019 & 1 & 46 & 9 & 22 & 1 & 2 & & $\mathbf{8 1}$ \\
\hline Štitník & 17 February 2019 & & 15 & 25 & 10 & & & & $\mathbf{5 0}$ \\
\hline Revúca & 17 February 2019 & & 11 & 2 & 22 & 1 & & & $\mathbf{3 6}$ \\
\hline Velký Šariš & 21 February 2019 & 3 & 25 & 10 & 5 & & & 1 & $\mathbf{4 4}$ \\
\hline \multicolumn{1}{|c|}{ Summary } & & $\mathbf{4 5}$ & $\mathbf{1 2 7 1}$ & $\mathbf{4 9 8}$ & $\mathbf{9 4 5}$ & $\mathbf{1 7 0}$ & $\mathbf{7 3}$ & $\mathbf{1 2 1}$ & $\mathbf{3 1 2 3}$ \\
\hline
\end{tabular}

Notes: * Čanády, Mošanský, 2013; ${ }^{* *}$ - Čanády, Mošanský, 2016.

(2008), this period represents the best time to study plumage phenotype distribution and the numbers of pigeons in cities, because only a few birds are breeding, or breeding has stopped altogether. Moreover, at this time, pigeons are found away from buildings at foraging sites. Pigeons were observed and counted for 1 hour at sites where these were abundant, for example, railway or bus stations, squares, marketing places, and other places where a pigeon flock was found. All the pigeons with different phenotypes were counted.

The urban areas of all the evaluated cities were characterized by panel housing blocks, tall buildings, churches, cafés and shops, which create an ideal synanthropic environment for feral pigeons. The fact that a significantly greater number of pigeons occupy older buildings in the city centers than areas in the outskirts of the city was confirmed (Sacchi et al., 2002). Plumage phenotypes in all the cities were recorded and determined using binoculars (Bresser Hunter 10x50, Grossfeld $119 / 1000 \mathrm{~m}$ ) according to the previous studies (see Čanády, Mošanský, 2013, 2016).

On the basis of our observations, six color plumage phenotypes and one group of individuals that had not been classified with any of these forms were distinguished (Čanády, Mošanský, 2013, 2016): (1) the blue-bar or wild phenotype, that is, a gray mantle with two dark wing bars, but many birds had a lilac shade, and the bands on the wings were brown instead of black; (2) the blanc or white phenotype, that is, white or almost white individuals; (3) the spread or black phenotype, that is, a completely melanic plumage; (4) the checker or lightly checker phenotype, that is, a checkered mantle with moderate dark spots; (5) the T-pattern or dark checker phenotype, that is, a dark mantle with small gray marks; (6) the rufous phenotype, that is, beige-and-grey plumage, sometimes with white elements, two brown stripes on the wings but no stripe on the tail, and a gloss on the neck; and finally (7) the others group, which included individuals with phenotypes that had not been classified with any of these forms. These patterns are all primarily determined genetically (Jonhston, Janiga, 1995) and differ by the surface of the dark area on the wings, which corresponds to different melanin deposition in the feathers (Haase et al., 1992).

Plumage phenotypes were firstly treated separately and then pooled as melanic (i.e., checker, T-pattern and spread phenotypes) or paler (wild and blanc) compared using the chi-square $\left(\chi^{2}\right)$ test. The relationships among city area and human density and color phenotypes were also explored with Spearman's correlation analysis $\left(\mathrm{r}_{\mathrm{s}}\right)$.

Data on city area $\left(\mathrm{km}^{2}\right)$ and human density (inhab. $/ \mathrm{km}^{2}$ ) were obtained from the Wikipedia web site (www.wikipedia. org). All the traits were coded in quantitative (number of pigeons for phenotype morphs) or ranked scales, that is, for city area ( 1 - less than $70 \mathrm{~km}^{2} ; 2-70-140 \mathrm{~km}^{2} ; 3$ - more than 140 $\left.\mathrm{km}^{2}\right)$ and for human density ( 1 - less than 500 inhab. $/ \mathrm{km}^{2} ; 2$ 500-1000 inhab. $/ \mathrm{km}^{2} ; 3$ - more than 1000 inhab. $\left./ \mathrm{km}^{2}\right)$. Such a division was subjective and served only to simplify further analyses.

The chi-square $\left(\chi^{2}\right)$ test and Spearman's correlation analysis $\left(r_{s}\right)$ were performed using MS Excel 2003 for Windows XP and the statistical analysis system GraphPad Prism, version 5.01 (Graph-Pad Software, Inc., San Diego, California, USA).

\section{Results}

The censuses counted a total of 3,123 feral pigeons, which were evaluated for plumage polymorphism (Table 2). The 

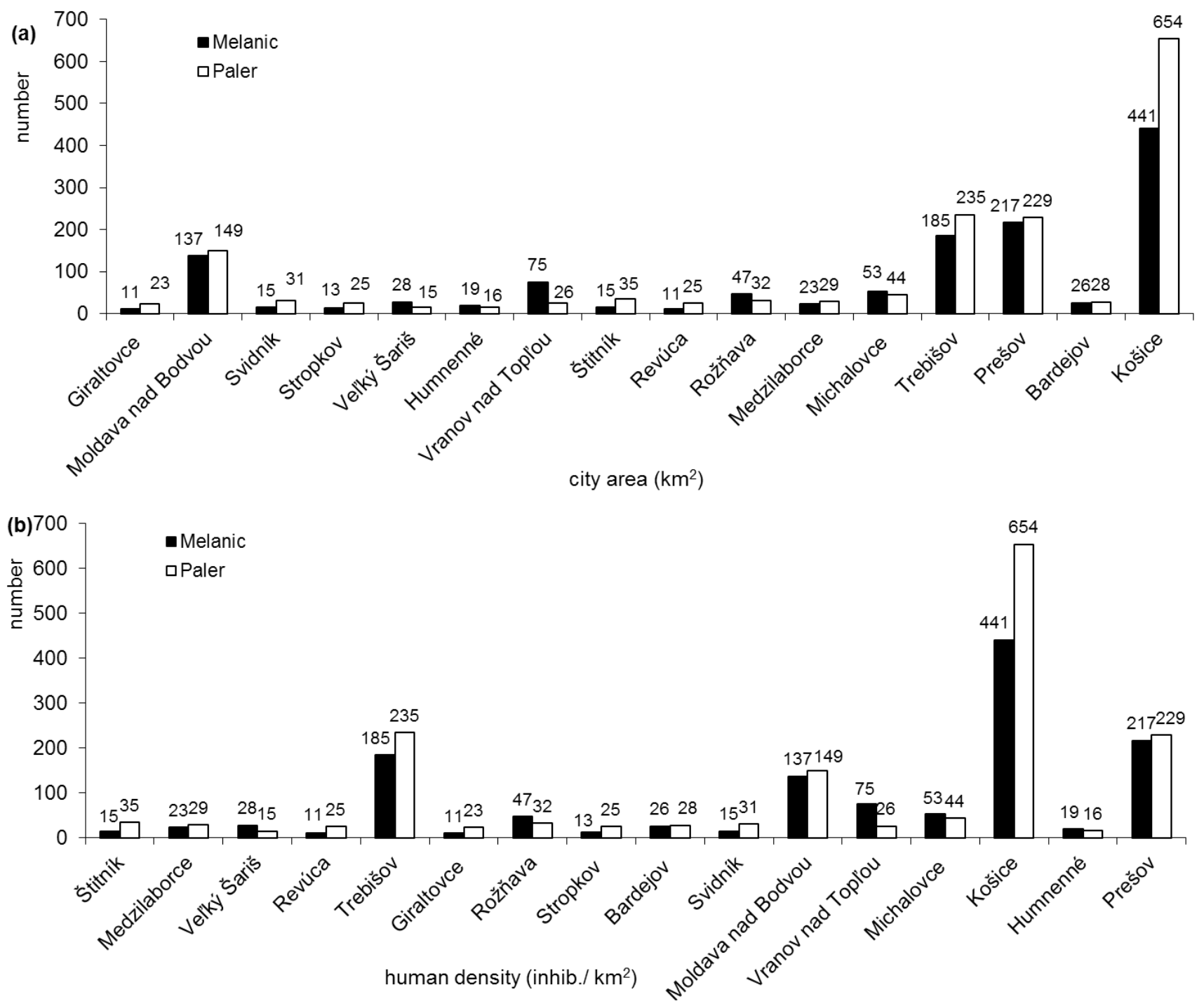

Fig. 1. Two plumage phenotypes (melanic and paler) distinguished in the population of feral pigeons (Columba liviaf. urbana) in the urban environments of Slovakian cities showed by (a) city area and (b) human density.

census of plumage patterns showed different frequencies for each of the studied cities (Figs $1 \mathrm{a}, \mathrm{b}$ ), with a predominance of paler pigeons for 11 cities. The distribution of both morph groups were also different according to pigeons, city area, and human density. Nevertheless, overall melanic birds predominated $(51.6 \%, \mathrm{n}=1.613)$, while paler birds $(42.6 \%, \mathrm{n}=1.316)$, were the second most frequent group. The frequency of birds with aberrant plumage color, that is, rufous and other phenotypes, varied and was higher in some cities. However, this prevalence was not influenced only by city size or population density (see Fig. 1). Rufous pigeons comprised $2.3 \%$ of the population, and $3.9 \%$ of the pigeon populations were not classified with any of the distinguished phenotypes (Table 2).

The chi-square test confirmed statistically significant differences between color phenotypes (Table 3 ) as well for the melanic and paler plumage phenotypes in pigeons occupying different cities $\left(\chi^{2}=81.49, \mathrm{df}=15, \mathrm{p}<0.0001\right)$. Our results confirmed the positive and significant relationships between melanic feathers and city area as well with human density in the cities (Table 4).

\section{Discussion}

Several authors showed that traits associated with darker coloration match those found in individuals exploiting urban and/ or stressful areas. Melanin-based coloration might reflect an adaptation to the urban environment because it brings some benefits that are also transmitted to future generations (Roulin, 2004; Jacquin et al., 2013a). Therefore, it represents a good precondition for investigating some ecological issues. According to this assumption, directional selection should favor this property, and the frequency of darker individuals should be higher than that of pale individuals in urban areas, which could result from differences in survival, reproductive success, and habitat 
Table 3. Chi-square test $\left(\chi^{2}\right)$ between the plumage color of feral pigeons (Columba livia f. urbana) from cities in Slovakia. Significant values were evaluated in level ${ }^{*} \mathrm{p}<0.05,{ }^{* *} \mathrm{p}<0.01,{ }^{* * *} \mathrm{p}<0.001$.

(a)

\begin{tabular}{|c|c|c|c|c|c|c|c|c|c|}
\hline & Stropkov & Svidník & Bardejov & Medzilaborce & Giraltovce & Humenné & Rožňava & Štítnik & Revúca \\
\hline Svidník & 8.63 & & & & & & & & \\
\hline Bardejov & $16.41^{*}$ & $12.85^{*}$ & & & & & & & \\
\hline Medzilaborce & 11.36 & $20.62^{* *}$ & $17.62^{* *}$ & & & & & & \\
\hline Giraltovce & 6.61 & $15.19^{*}$ & $21.20^{* * *}$ & 8.31 & & & & & \\
\hline Humenné & $12.62^{*}$ & 9.68 & 3.78 & $19.76^{* *}$ & $16.95^{* *}$ & & & & \\
\hline Rožňava & $24.79^{* * *}$ & $25.32^{* * *}$ & 8.36 & $18.16^{* *}$ & $27.38^{* * *}$ & $11.13^{*}$ & & & \\
\hline Štítnik & $26.85^{* * *}$ & $16.59^{*}$ & $15.40^{* *}$ & $37.07^{* * *}$ & $26.21^{* * *}$ & 7.79 & $24.50^{* * *}$ & & \\
\hline Revúca & $13.72^{*}$ & $16.77^{*}$ & $12.46^{*}$ & 8.86 & $21.52^{* * *}$ & $13.39^{*}$ & $12.63^{*}$ & $24.07^{* * *}$ & \\
\hline Velký Šariš & $21.86^{* *}$ & $21.75^{* *}$ & 8.78 & $28.57^{* * *}$ & $23.13^{* * *}$ & 8.30 & 9.14 & $12.54^{*}$ & $25.06^{* * *}$ \\
\hline
\end{tabular}

(b)

\begin{tabular}{|l|l|l|c|c|c|}
\hline & Košice & Prešov & Vranov nad Toplou & Michalovce & Trebišov \\
\hline Prešov & $76.86^{* * *}$ & & & & \\
\hline Vranov nad Toplou & $65.48^{* * *}$ & $33.16^{* * *}$ & & & \\
\hline Michalovce & $32.00^{* * *}$ & $17.32^{* *}$ & $24.04^{* * *}$ & & \\
\hline Trebišov & $123.4^{* * *}$ & $37.36^{* * *}$ & $40.72^{* * *}$ & $13.23^{*}$ & \\
\hline Moldava nad Bodvou & $47.22^{* * *}$ & $57.94^{* * *}$ & $40.58^{* * *}$ & $37.39^{* * *}$ & $105.9^{* * *}$ \\
\hline
\end{tabular}

selection. This assumption has also been supported by the results observed in some birds (Roulin, Altwegg, 2007; Roulin et al., 2010; Van den Brink et al., 2012; Saino et al., 2013).

Our results confirmed that the distribution of color phenotypes was rather heterogeneous for each studied city. Although the chi-square $\left(\chi^{2}\right)$ test confirmed the overall predominance of the melanic type across cities and towns, the paler pigeons prevailed in 11 of them. These findings were in accordance with the observations made by Obukhova $(2001,2007)$ that pigeon populations were characterized by a polymorphism of color patterns with different phenotype frequencies. She also showed the existence of different conditions for the origin of the urban populations of feral pigeon and consequent high genetic heterogeneity of this species. On the basis of these findings, she assumed that the key aspect of color polymorphism in feral pigeon was synurbization, that is, anthropogenic evolution. Later, she also demonstrated changes in the frequency of distribution of several plumage color phenotypes during the 30-year dynamics (from 1978 to 2008) in Moscow (Obukhova, 2007). Mainly she showed that, the frequency of the melanic phenotype decreased as a result of a decrease in the total pigeon population size and, consequently, population density in colonies. This change led to increased proportions of wild type and aberrantly colored birds throughout the city and an increased frequency of transitory phenotypes in the central region. An increase in the proportion of aberrant phenotypes suggests an increase in the genetic heterogeneity of the populations. The proportion of strongly melanic pigeons was higher in urbanized area, suggesting different selective pressures along an urbanization gradient.

Pigeons colonize cities from their center to the periphery and live in a highly urban environment, where they utilize the resources provided by the urban environment. They depend directly on processes that take place in the social structure of the human population, and changes in the structure of the urban
Table 4. Spearman's correlation coefficients $\left(r_{s}\right)$ between the plumage color of feral pigeons (Columba livia f. urbana) and city area and human density in Slovakia. Significant values were evaluated in level ${ }^{*} \mathrm{p}<0.05,{ }^{* *} \mathrm{p}<0.01$.

\begin{tabular}{|l|c|c|}
\hline & city area $\left.\mathbf{( k m}^{\mathbf{2}}\right)$ & $\begin{array}{c}\text { human density } \\
\text { (inhab././km } \mathbf{~})\end{array}$ \\
\hline Blanc & 0.42 & 0.18 \\
\hline Wild & $0.51^{*}$ & 0.08 \\
\hline Checker & 0.36 & 0.06 \\
\hline T-pattern & $0.58^{*}$ & 0.19 \\
\hline Spread & $0.74^{* *}$ & 0.62 \\
\hline Rufous & $0.68^{*}$ & 0.32 \\
\hline other & $0.83^{*}$ & 0.31 \\
\hline
\end{tabular}

pigeon population reflect changes in the human population and vice versa. Pigeon populations respond adaptively to dramatic alterations in environmental conditions, such as changes in the amount and accessibility of food and nesting places. When feeding resources are poorer due to social anthropogenic factors, the pigeon population size decreases. This leads to changes in the phenotype frequencies, which are an adaptive response of the population to environmental changes (Obukhova, 2007).

Nevertheless, our results, as well the above-cited studies, show that paler morphs also represent a very significant part of the pigeon population in urban areas. Jacquin et al. (2011) assumed that despite benefits in term of blood parasite resistance, being darker also entails some costs. Gasparini et al. (2009) showed a stronger immune response in melanic birds but at the cost of a greater body mass loss. Similarly, darker morphs could be more resistant to endoparasites, such as blood parasites, but more susceptible to other parasites, such as ectoparasites 
(Chakarov et al., 2008). According to these findings, different selection pressures by parasites may lead to the favoring of intermediate morphs (e.g., heterozygous advantage) in a population, thus promoting the maintenance of polymorphisms in environments with both types of parasites. This is because each morph could be better adapted to different types of parasites or to alternative exposure levels (Roulin, 2004). The positive relationships between immune responsiveness and parasite intensity with different coloration (e.g., Jacquin et al., 2011; Gasparini et al., 2011) suggests that melanin-based coloration could also play an important role in sexual selection (Burley, 1977), that is, in captivity, females and males of feral pigeons tend to prefer darker-colored partners. Therefore, it cannot be totally excluded that mate choice according to coloration could also depend on the presence of parasites in the environment (Jacquin et al., 2011).

All the above-mentioned observations give a partial explanation of why the less amount in dark forms was confirmed in 11 Slovakia cities (see Fig. 1) but coupled with a higher frequency of aberrant color types. This is also highlighted by the fact that a decrease in the feral pigeon population in the historical center of Košice city over the last decades was confirmed (Čanády, Mošanský, 2013). However, this explanation seems to be too simple, and there is likely to be a combination of multiple factors affecting the overall maintenance of individual color phenotypes (Roulin, 2004, 2009; Roulin, Altwegg, 2007; Roulin et al., 2000; 2001, 2008, 2010; Obukhova, 2001, 2007; Ducrest et al., 2008; Gasparini et al., 2011; Jacquin et al., 2011, 2012, 2013a,b; Van den Brink et al., 2012; Saino et al., 2013).

In contrast, the directional change in the frequency of aberrant phenotypes also opens up a very interesting issue, that is, pressure from predators (see Obukhova, 2007). It was thus also due to the overall success of attacks on pigeons with different phenotypes by predatory birds, such as hawks, falcons, or packs of crows, or by town predators, such as cats or dogs, depending on how distinguishable the plumage color was from a flock. Mikula et al. (2013) noted an increase in several raptors, such as Accipiter gentilis (Linnaeus, 1758), A. nisus (Linnaeus, 1758), Falco tinnunculus (Linnaeus, 1758), and Buteo buteo (Linnaeus, 1758), in urban environments in recent decades, although urbanization has also been associated with a decreased abundance of raptors that keep a safe distance from humans (Díaz et al., 2013; Mikula et al., 2013; Mikula 2014; Tryjanowski et al., 2016). Chace, Walsh (2006) showed that this was caused by changes in the food supply, and predators' habituation to novel nesting substrates may further influence the spectrum of predators in urban habitats and subsequently change predation risk for urban birds (Chace, Walsh, 2006). Nevertheless, urban birds are threatened more often by mammalian predators, such as cats and dogs or by disturbance from humans (Møller, 2008; Møller, Ibáñez-Álamo, 2012; Mikula et al., 2013; Tryjanowski et al., 2016). According to the cited studies, urban birds are typically exposed to moving cats, dogs, or humans and, therefore, could have consistently lower flight initiation distance (FIDs) than birds from rural sites (more often threatened by avian predators). For example, Mikula (2014) estimated the FIDs for feral pigeon to be only $2.78 \mathrm{~m}$.

Nevertheless, interpreting FID results this broadly can be tricky, as it is always measured as a response given to approaching humans, yet it is usually considered to be a general fear (anti-predatory) response against any non-flying predators (including humans) - which is likely overly simplifying as a citydweller bird can surely make a difference between a passing by human (low threat level, i.e., harmless in most of the cases) and a cat (seldom if ever harmless) see (Blumstein, 2014; Vincze et al., 2019).

Chace, Walsh (2006) assumed that avian communities could be differentially affected when city districts differ in the composition (predominantly mammalian or avian) and density of their predator fauna. This may also be a factor that is important for affecting the population size and for maintaining melanic color phenotypes in the stable and healthy pigeon population.

Also, several explanations were proposed for feral pigeons, in relation to explaining color polymorphism, such as differential adaptation to urban conditions (Johnston, Janiga, 1995), parasites (Jacquin et al., 2011, 2013a, b), or food availability (Jacquin et al., 2012). Récapet et al. (2013) showed that eumelanin-based coloration was under directional survival selection in dense populations of highly urbanized areas and that such selection occurs through the differential survival or dispersal rate of juveniles. They also assume that interactions between melaninbased coloration and population densities (see also Obukhova, 2011) could explain the observed differences in local survival. Moreover, a positive correlation between urbanization level and the proportion of dark phenotypes was found within the urban areas of several European cities (Obukhova, 2001, 2007; Jacquin et al., 2013b; Récapet et al., 2013). The results obtained in these studies confirmed the differences in fitness and/or habitat choice between dark and pale pigeons in urban areas.

To conclude, this study provides knowledge on melaninbased coloration in feral pigeons from Slovakia. Our findings thus contribute to the growing body of evidence that darker eumelanic individuals in urban environments have a higher abundance than paler ones. A current survey of color variation in pigeons from free-living populations in various cities of Slovakia may yield interesting information on the environmental correlates of coloration-dependent local survival. We also observed differences in the number of color phenotypes according to city size and/or human density, which were consistent with such effects, but future long-time studies are needed to provide sufficient data to confirm them in full. Moreover, our results are in agreement with the assumption that melanin-based coloration reflects an adaptation to the urban environment or to stressful factors to which urban birds are more exposed.

Acknowledgements

Our thanks also go to anonymous referees for their valuable comments on the manuscript and to David McLean for revising the English language.

\section{References}

Blumstein, D.T. (2014). Attention, habituation, and antipredator behaviour: implications for urban birds. In D. Gil \& H. Brumm (Eds.), Avian urban ecology (pp. 41-53). Oxford: Oxford University Press.

Burley, N. (1977). Parental investment, mate choice, and mate quality. Proc. Natl. Acad. Sci. U.S.A., 74, 3476-3479.

Chace, J.F. \& Walsh J.J. (2006). Urban effects on native avifauna: a review. Landsc. Urban Plann., 74, 46-69. DOI: 10.1016/j.landurbplan.2004.08.007. 
Chakarov, N., Boerner, M. \& Krüger O. (2008). Fitness in common buzzards at the cross-point of opposite melaninparasite interactions. Funct. Ecol., 22, 1062-1066. DOI: 10.1111/j.1365-2435.2008.01460.x.

Chatelain, M., Gasparini, J. \& Frantz A. (2016). Do trace metals select for darker birds in urban areas? An experimental exposure to lead and zinc. Global Change Biol., 22, 2380-2391. DOI: 10.1111/gcb.13170.

Chatelain, M., Gasparini, J., Jacquin, L. \& Frantz A. (2014). The adaptive function of melanin-based plumage coloration to trace metals. Biol. Lett., 10(3), 20140164. DOI: 10.1098/rsbl.2014.0164.

Čanády, A. \& Mošanský L. (2013). Population size and plumage polymorphism of feral pigeon (Columba livia forma urbana) from urban environment of Kosice city (Slovakia). Zool. Ecol., 23(2), 104-110. DOI 10.1080/21658005.2013.797149.

Čanády, A. \& Mošanský L. (2016). Plumage colour patterns and density of feral pigeon from urban areas of the Stropkov and Svidník cities (Ondavská Vrchovina Mts, Slovakia). Folia Oecologica - Acta Universitatis Prešoviensis, 8(2), 5-13.

Čanády, A. \& Mošanský L. (2017). Public Cemetery as a biodiversity hotspot for birds and mammals in the urban environment of Košice city (Slovakia). Zool. Ecol., 27(3-4), 185-195. DOI: 10.1080/21658005.2017.1366024.

Díaz, M., Møller, A.P., Flensted-Jensen, E., Grim, T., Ibáñez-Álamo, J.D., Jokimäki, J., Markó, G. \& Tryjanowski P. (2013). The geography of fear: A latitudinal gradient in anti-predator escape distances of birds across Europe. PloS One, 8, e64634. DOI: 10.1371/journal.pone.0064634.

Ducrest, A.L., Keller, L. \& Roulin A. (2008). Pleiotropy in the melanocortin system, coloration and behavioural syndromes. Trends Ecol. Evol., 23(9), 502-510. DOI: 10.1016/j.tree.2008.06.001.

Ferman, L.M., Peter, H.-U. \& Montalti D. (2010). A study of feral pigeon Columba livia var. in urban and suburban areas in the city of Jena, Germany. Arx. de Misc. Zoo., 8, 1-8. DOI: 10.32800/amz.2010.08.0001.

Gasparini, J., Bize, P., Piault, R., Wakamatsu, K., Blount, J.D., Ducrest, A.L. \& Roulin A. (2009). Strength and cost of an induced immune response are associated with a heritable melanin-based colour trait in female tawny owls. J. Anim. Ecol., 78(3), 608-616. DOI: 10.1111/j.13652656.2008.01521.x

Gasparini, J., Erin, N., Bertin, C., Jacquin, L., Vorimore, F., Frantz, A., Lenouvel, P. \& Laroucau K. (2011). Impact of urban environment and host phenotype on the epidemiology of Chlamydiaceae in feral pigeons (Columba livia). Environ. Microbiol., 13(12), 3186-3193. DOI: 10.1111/j.1462-2920.2011.02575.x.

Haase, E., Ito, S., Sell, A. \& Wakamatsu K. (1992). Melanin concentrations in feathers from wild and domestic pigeons. J. Hered., 83(1), 64-67.

Hetmański, T. (2008). Variation in plumage colours and patterns of the Feral Pigeon Columba livia in Pomerian cities (in Polish). In P. Indykiewicz, L. Jerzak \& T. Barczak (Eds.), Fauna Miast. Ochronić Różnorodność Bioticzna W Miastach (pp. 623-628). Bydgoszcz: Uniwersytet Technologiczno-Pryrodnoczy w Bydgoszcz oraz Uniwersytet Zielonogórski w Zielonej Górze.

Hetmański, T. \& Jarosiewicz A. (2008): Plumage polymorphism and breeding parameters of various feral pigeon (Columba livia GM.) morphs in urban area Gdańsk (Poland). Pol. J. Ecol., 56(4), 683-691.

Jacquin, L., Cazelles, B., Prévot-Julliard, A.C., Leboucher, G. \& Gasparin J. (2010). eproduction management affects breeding ecology and reproduction costs in feral urban pigeons (Columba livia). Can. J. Zool. 88(8), 781-787. DOI: 10.1139/Z10-044.

Jacquin, L., Lenouvel, P., Haussy, C., Ducatez, S. \& Gasparini J. (2011). Melanin-based coloration is related to parasite intensity and cellular immune response in an urban free living bird: the feral pigeon Columba livia. J. Avian Biol., 42, 11-15. DOI: 10.1111/j.1600-048X.2010.05120.x.

Jacquin, L., Récapet, C., Bouche, P., Leboucher, G. \& Gasparini J. (2012) Melanin-based coloration reflects alternative strategies to cope with food limitation in pigeons. Behav. Ecol., 23, 907-913. DOI: 10.1093/ beheco/ars 055 .

Jacquin, L., C. Haussy, C., Bertin, C., Laroucau, K. \& Gasparini J. (2013a). Darker female pigeons transmit more specific antibodies to their eggs than do paler ones. Biol. J. Linn. Soc., 108, 647-675. DOI: 10.1111/ bij.12001.

Jacquin, L., Récapet, R.E., Prevot-Julliard, C., Leboucher, A.C., Lenouvel, G., Erin, P., Frantz, N., Corbel, A. \& Gasparini J. (2013b). A potential role for parasites in the maintenance of bird color polymorphism in cities. Oecologia, 173, 1089-1099. DOI: 10.1007/s00442-013-2663-2.
Janiga, M. (1991). Colour polymorphism in Feral Pigeons (Columba livia Gm. 1789). Acta Fac. Rerum Nat. Univ. Comenianae, Zool., 34, 31-36.

Johnston, R.F. \& Janiga M. (1995). Feral pigeons. New York: Oxford University Press.

Jokimäki, J. \& Suhonenm J. (1998). Distribution and habitat selection of wintering birds in urban environments. Lands. Urban Plann., 34, 253 263. DOI: 10.1016/S0169-2046(97)00089-3.

Kowalski, J., Indykiewicz, P. \& Frieske A. (2011). Population size and plumage polymorphism in Feral Pigeon Columba livia var. urbana in the city of Bydgoszcz (Poland). In P. Indykiewicz, L. Jerzak, J. Böhner \& B. Kavanagh (Eds.), Urban fauna. Studies of animal biology, ecology and conservation in European cities (pp. 435-447). Bydgoszc: University of Technology and Life Science in Bydgoszcz.

Lofts, B., Murton, R.K. \& Westwood N.J. (1966). Gonadal cycles and the evolution of breeding seasons in British Columbidae. J. Zool., 150, 249-272.

Mikula, P. (2014). Pedestrian density influences flight distances of urban birds. Ardea 102(1), 53-61. DOI: 10.5253/078.102.0105.

Mikula, P., Hromada, M. \& Tryjanowski P. (2013). Bats and Swifts as food of the European Kestrel (Falco tinnunculus) in a small town in Slovakia. Ornis Fenn., 90, 178-185.

Møller, A.P. (2008). Flight distance of urban birds, predation, and selection for urban life. Behav. Ecol. Sociobiol., 63(1), 63-75. DOI: 10.1007/ s00265-008-0636-y.

Møller, A. P. \& Ibáñez-Álamo,J. D. (2012). Escape behaviour of birds provides evidence of predation being involved in urbanization. Anim. Behav., 84(2), 341-348. DOI:10.1016/j.anbehav.2012.04.030.

Obukhova, N.Y. (2001). Geographic variation of color in the synanthropic Blue Rock Pigeon. Russ. J. Genet., 37, 649-658.

Obukhova, N.Y. (2007). Polymorphism and phene geography of the blue rock pigeon in Europe. Russ. J. Genet., 43(5), 492-501.

Obukhova, N.Y. (2011). Dynamics of balanced polymorphism morphs in blue rock pigeon Columbia livia. Russ. J. Genet., 47(1), 83-89.

Pardo, E., Bracamontes, J. \& Begambre M. (2018). Variabilidad genética de las poblaciones de palomas domésticas (Columba livia) en Sincelejo, Sucre. Rev. de Investig. Vet. del Perú, 29(1), 55-63. DOI: 10.15381/rivep. v29i1.14198.

Przybylska, K., Haidt, A., Myczko, Ł., Ekner, A., Rosin, Z.M., Kwieciński, Z., Tryjanowski, P., Suchodolska, J., Takacs, V., Jankowiak, Ł. Tobółka, M., Wasielewski, O., Graclik, A., Krawczyk, A. J., Kasprzak, A., Szwajkowski, P., Wylegała, P., Malecha, A.W., Mizera, T. \& Skórka P. (2012).Local and landscape-level factors affecting the density and distribution of the Feral Pigeon Columba livia var. domestica in an urban environment. Acta Ornithol., 47, 37-45. DOI 10.3161/000164512X653908.

Récapet, C., Dauphin, L., Jacquin, L., Gasparini, J. \& Prévot-Julliard A.C. (2013). Eumelanin-based colouration reflects local survival of juvenile feral pigeons in an urban pigeon house. J. Avian Biol., 44(6), 583-590. DOI: $10.1111 /$ j.1600-048X.2013.00087.x.

Roulin, A., Jungi, T.W., Pfister, H. \& Dijkstra C. (2000). Female barn owls (Tyto alba) advertise good genes. Proc. R. Soc. B., 267(1446), 937-941. DOI: 10.1098/rspb.2000.1093.

Roulin, A., Riols, C., Dijkstra, C. \& Ducrest A.L. (2001). Female plumage spottiness signals parasite resistance in the barn owl (Tyto alba). Behav. Ecol., 12(1), 103-110. DOI: 10.1093/oxfordjournals.beheco.a000371.

Roulin, A. (2004). The evolution, maintenance and adaptive function of genetic colour polymorphism in birds. Biol. Rev., 79(4), 815-848. DOI $10.1017 /$ S1464793104006487.

Roulin, A. \& Altwegg R. (2007). Breeding rate is associated with pheomelanism in male and with eumelanism in female barn owls. Behav. Ecol. 18, 563-570. DOI: 10.1093/beheco/arm015.

Roulin, A., Gasparini, J., Bize, P., Ritschard, M. \& Richner H. (2008). Melanin-based colorations signal strategies to cope with poor and rich environments. Behav. Ecol. Sociobiol., 62, 507-519.

Roulin, A. (2009). Melanin-based coloration covaries with ovary size in an age-specific manner in the barn owl. Naturwissenschaften, 96(10), 1177-1184.

Roulin, A., Altwegg, R., Jensen, H., Steinsland, I. \& Schaub M. (2010). Sexdependent selection on an autosomal melanic female ornament promotes the evolution of sex ratio bias. Ecol. Lett., 13, 616-626. DOI: 10.1111/j.1461-0248.2010.01459.x. 
Saari, L. (1997). Columba livia. In W.J. Hagemeijer \& M.J. Blair (Eds.), The EBCC Atlas of European breeding birds: their distribution and abundance (pp. 380-381). London: T \& A.D. Poyser.

Sacchi, R., Gentilli, A., Razzetti, E. \& Barbieri F. (2002). Effects of building features on density and flock distribution of feral pigeons Columba livia var. domestica in an urban environment. Can. J. Zool., 80, 48-54. DOI: 10.1139/z01-202.

Saino, N., Romano, M., Rubolini, D., Ambrosini, R., Caprioli, M., Milzani, A., Costanzo, A., Colombo, G., Canova, L. \& Wakamatsu K. (2013) Viability is associated with melanin-based coloration in the barn swallow (Hirundo rustica). PLoS One, 8, e60426. DOI: 10.1371/journal. pone.0060426.

Tryjanowski, P., Moller, A.P., Morelli, F., Biaduń, W., Brauze, T., Ciach M., Czechowski, P., Czyż, S., Dulisz, B., Goławski, A., Hetmański, T., Indykiewicz, P., Mitrus, C., Myczko, Ł, Nowakowski, J.J., Polakowski, M., Takacs, V., Wysocki, D. \& Zduniak P. (2016): Urbanization affects neophilia and risk-taking at bird-feeders. Sci. Rep., 6, e28575. DOI: 10.1038/srep28575
Tryjanowski, P., Morelli, F., Mikula, P., Krištín, A. Indykiewicz, P., Grzywaczewski, G., Kronenberg, J. \& Jerzak L. (2017). Bird diversity in urban green space: A large-scale analysis of differences between parks and cemeteries in Central Europe. Urban For. Urban Green., 27, 264-271. DOI: 10.1016/j.ufug.2017.08.014.

Van den Brink, V., Dreiss, A.N. \& Roulin A. (2012). Melanin-based coloration predicts natal dispersal in the barn owl, Tyto alba. Anim. Behav., 84, 805-812. DOI: 10.1016/j.anbehav.2012.07.001.

Vickrey, A.I., Bruders, R., Kronenberg, Z., Mackey, E., Bohlender, R.J., Maclary, E.T., Maynez, R., Osborne, E.J., Johnson, K.P., Huff, Ch.D., Yandell, M. \& Shapiro M.D. (2018). Introgression of regulatory alleles and a missense coding mutation drive plumage pattern diversity in the rock pigeon. Elife, 7, e34803. DOI: 10.7554/eLife.34803.001.

Vincze, E., Pipoly, I., Seress, G., Preiszner, B., Papp, S., Németh, B., Liker A. \& Bókony V. (2019). Great tits take greater risk toward humans and sparrowhawks in urban habitats than in forests. Ethology, 125(10), 686-701. DOI: 10.1111/eth.12922. 